\title{
Analysis of the Effect of Menstrual Cycle Phases on Aerobic-Anaerobic Capacity and Muscle Strength
}

\author{
Bereket Köse \\ Correspondence: Bereket Köse, School of Physical Education and Sport, Sirnak University, Sirnak, Turkey
}

Received: April 13, 2018

doi:10.11114/jets.v6i8.3207

Accepted: May 25, $2018 \quad$ Online Published: June 8, 2018

URL: https://doi.org/10.11114/jets.v6i8.3207

\begin{abstract}
The objective of this study is to examine the effect of menstrual cycle phases on aerobic-anaerobic capacity and muscle strength. 10 female kickboxing athletes with an average age of $21.40 \pm 2.01$ years; average height of $169.60 \pm 6.14 \mathrm{~cm}$; average weight of $63.90 \pm 5.76 \mathrm{~kg}$ and average training age of $7.41 \pm 2.10$ participated in the study. On the first day, maximal strength (1RM), strength endurance, wingate anaerobic power and capacity test (WAnT) were conducted and aerobic measurements were taken the next day. The measurements were conducted in follicular phase on the days $2-3^{\text {rd }}$ of menstrual bleeding, in mid-follicular phase on $8-9^{\text {th }}$ days and in luteal phase on $22-23^{\text {th }}$ days. The data were analyzed with Friedman repeated measurements variance analysis. According to the results of the study, it was found that kickboxing athletes' aerobic-anaerobic capacity, 1RM, strength endurance and heart rate (HR) were not affected by follicular phase, mid-follicular phase and luteal phase ( $p>0.005$ ). As a conclusion, it can be said that menstrual cycle does not influence performance parameters such as muscle strength, muscle endurance and aerobic-anaerobic capacity.
\end{abstract}

Keywords: Aerobic, anaerobic, kickboxing, menstrual cycle, strength

\section{Introduction}

Menstrual cycle is some of the regular changes in the whole organism of women, especially in reproductive organs, which continue from menarche to menopause so that the function of reproduction can continue as normal (Turan \& Ceylan, 2007). The interaction of hypothalamus, hypophis, uterus, prostaglandin and neuroendocrin factors with each other is within this structure (Rosenfeld, 2009). Menstrual cycle is a physiological phenomenon which repeats every $28 \pm 3$ days and which covers 30-35 years of a woman's life (Arı̈z \& Ege, 2013). In general, this cycle can be grouped as three phases as follicular (from day 1 to day 14), ovulation (the middle of menstruation) and luteal phase (days 15 to 28) (Janse, 2003; Kabalak \& Tüzün, 2004; Nattiv et al., 2007; Saladin, 2016). It is thought that fluctuations in women's hormone levels during their lives which continue from adolescence to menopause cause physiological, biological, metabolic and psychological changes. Female sex hormones influence great number physiological and physical parameters that can influence athletic performance (Reneta \& Constance, 2000). Various studies have shown that due to hormonal fluctuations in the organism during menstrual cycle, there may occur changes in aerobic, anaerobic and muscle strength. In addition, various authors have researched and are still continuing to research whether different phases of menstrual cycle have an influence on risk of injury (Beynonn et al., 2006), anaerobic power (Tsampoukos et al., 2010), sport performance (Oosthuyse et al., 2010), muscle strength (Loureiro et al., 2011), flexibility (Bell et al., 2009) and cardiovascular mechanisms (Bai et al., 2009; Fu et al., 2010; Karabag et al., 2011). Indeed, while some studies have shown that menstrual cycle phases influence sportive performance (Jaffre et al., 2006; Gordon et al., 2013), other studies show that these phases do not have an influence on performance (Giacomoni et al., 2000; Smekal et al., 2007). In the light of this information, the purpose of this study is to find out the influence of menstrual cycle phases of women who study in the faculty of sport sciences and who do kickboxing, on aerobic-anaerobic capacity, maximal strength and strength endurance.

\section{Method}

\subsection{Participant}

10 women doing kickboxing sport and studying in the faculty of sport sciences participated in the study voluntarily. While average age of the participants was $21.40 \pm 2.01$ years, their average height was $169.60 \pm 6.14 \mathrm{~cm}$, average weight was $63.90 \pm 5.76 \mathrm{~kg}$ and average training age was $7.41 \pm 2.10$. Approval was taken from Sirnak University ethical board to conduct the study. 


\subsection{Measurements}

Firstly, the participants' heights were measured with Harpenden stadiometer (Holtain, U.K.) and their weights were found with Plus Avis 333 (Jawon Medical, South Korea) make bioelectric impedance analyzer. Later, in the three different phases of menstrual cycle, maximal strength and strength endurance tests, WAnT test after a 30-minute rest and aerobic capacity test on the next day were conducted, respectively. Before the tests, participants' rested heart rates were recorded. Each of the three phase measurements were conducted randomly between 10.00- 12.00 and at least 2 hours after breakfast. None of the subjects got any medical support during menstrual cycle which took place during the tests and did not use any medication. Participants who had an irregular menstrual cycle, those who had a chronic illness and those who were having hormone therapy were not included in the study. Menstrual cycle during the test period was followed with the number of days and the tests were conducted in the follicular phase between the $2-3^{\text {rd }}$ days of the first bleeding, on the 8 and $9^{\text {th }}$ days of mid-follicular phase and on the 22 and $23^{\text {th }}$ days of luteal phase (pre-menstrual phase). The subjects were asked not to have intense training and not to consume alcohol a day before they took the tests.

\subsection{Research Design}

Maximal strength (1RM) and strength endurance test: 1 repetition maximum (1RM) and strength endurance test were conducted according to NSCA guide (Miller et al., 2012). Following these, the participants did Bench Press in three different phases of menstrual phase with 1RM and until they exhausted with 65\% of 1RM.

Anaerobic power test: WAnT test was used to find out anaerobic power and capacity. Test was conducted with Monark 894-E model device (Monark, Sweden). Before starting the test, the participants warmed up for five minutes with 60-70 rpm speed with no weight in the basket. In the second and fourth minutes of the warm up, they cycled maximally for five seconds with no weight in the basket, again. After three minutes of passive rest on the bicycle, the test started. Weights of $7.5 \%$ of the participants' body weights were placed in the basket. The test was conducted with maximal effort of the participant for 30 seconds.

Aerobic capacity test: On the next day, participants' running distance and heart rates were measured by using Bruce protocol. Bruce protocol starts with $2.7 \mathrm{~km} / \mathrm{speed}$ and $10 \%$ slope and the slope and speed increase every three minutes. The test continues until the athlete is exhausted or reaches the specified criteria (Heyward \& Gibson, 2014).

\subsection{Statistical Analysis}

SPSS- 23 program was used for data analysis. "Shapiro Wilks" test was used to find out whether the data were normally distributed. In case of normally distributed data, one way variance analysis "Repeated Measures" method was used. When the data were not normally distributed, "Variance Analysis in Friedman Repeated Measurements" was used. Confidence interval of $\mathrm{p}<0.05$ was used for all statistical procedures.

\section{Results}

Participants' WAnT, 1RM, strength endurance, running times and HR values are shown in Table 1, Table 2 and Table 3 respectively. When the results were examined, it was found that none of the values obtained in 3 different phases of menstrual cycle were statistically significant ( $p>0.005)$.

Table 1. Participants' HR and WAnT values from the three different phases of menstrual cycle

\begin{tabular}{|c|c|c|c|c|}
\hline \multirow[t]{2}{*}{$\mathrm{n}=10$} & $\begin{array}{c}\text { Follicular Phase } \\
\left(2-3^{\text {th }} \text { day }\right)\end{array}$ & $\begin{array}{c}\text { Mid-Follicular Phase } \\
\left(8-9^{\text {th }} \text { day }\right)\end{array}$ & $\begin{array}{l}\text { Luteal Phase } \\
\left(22-23^{\text {th }} \text { day }\right)\end{array}$ & \multirow[b]{2}{*}{$\mathbf{P}$} \\
\hline & Mean \pm SD & Mean \pm SD & Mean \pm SD & \\
\hline Rest HR (bpm) & $72.14 \pm 6.78$ & $70.98 \pm 8.16$ & $71.16 \pm 7.55$ & 0.657 \\
\hline $\mathrm{PP}(\mathrm{w})$ & $554.56 \pm 109.00$ & $556.06 \pm 146.18$ & $555.50 \pm 107.29$ & 0.303 \\
\hline $\mathrm{AP}(\mathrm{w})$ & $379.43 \pm 69.23$ & $366.84 \pm 76.41$ & $377.75 \pm 66.86$ & 0.250 \\
\hline $\mathrm{MP}(\mathrm{w})$ & $206.75 \pm 94.08$ & $198.78 \pm 45.93$ & $193.80 \pm 56.45$ & 0.450 \\
\hline $\mathrm{DP}(\%)$ & $59.25 \pm 5.12$ & $62.99 \pm 9.04$ & $64.47 \pm 9.89$ & 0.417 \\
\hline Peak HR (bpm) & $185.00 \pm 8.18$ & $183.00 \pm 6.24$ & $184.00 \pm 5.56$ & 0.761 \\
\hline
\end{tabular}

${ }_{\text {Rest }} \mathrm{HR}$ (bpm/min): Rest heart rate; PP: Peak power; AP: Average power; MP: Minimum power; DP: Drop power; Peak HR (bpm): Peak heart rate; bpm: Per minute beat; Min: minute; Sd: Standard deviation

Table 2. Participants' maximal strength (1RM) and strength endurance (65\%) repetition numbers obtained through

Bench Press in three different phases of menstrual cycle

\begin{tabular}{ccccc}
\hline \multirow{2}{*}{$\mathrm{n}=10$} & $\begin{array}{c}\text { Follicular Phase } \\
\left(\mathbf{2 - 3 ^ { \text { th } }} \mathbf{d a y}\right)\end{array}$ & $\begin{array}{c}\text { Mid-Follicular Phase } \\
\left.\mathbf{( 8 - 9}^{\text {th }} \mathbf{d a y}\right)\end{array}$ & $\begin{array}{c}\text { Luteal Phase } \\
\left(\mathbf{2 2 - 2 3}^{\text {th }} \mathbf{d a y}\right)\end{array}$ & \multirow{2}{*}{ P } \\
\cline { 2 - 5 } & $\mathbf{M e a n} \pm$ SD & $\mathbf{M e a n} \pm$ SD & Mean \pm SD & \\
\hline Bench Press (1RM) & $41.20 \pm 6.54$ & $41.70 \pm 6.40$ & $41.65 \pm 6.72$ & 0.324 \\
\hline Bench Press (65\%) & $20.88 \pm 6.45$ & $20.55 \pm 4.41$ & $21.15 \pm 6.08$ & 0.549 \\
\hline
\end{tabular}


1RM: Repetition maximum; Sd: Standard deviation

Table 3. Participants' aerobic test and maximal heart rate values in three different phases of the menstrual cycle

\begin{tabular}{|c|c|c|c|c|}
\hline \multirow[t]{2}{*}{$\mathrm{n}=10$} & $\begin{array}{c}\text { Follicular Phase } \\
\left(2-3^{\text {th }} \text { day }\right)\end{array}$ & $\begin{array}{c}\text { Mid-Follicular Phase } \\
\left(8-9^{\text {th }} \text { day }\right)\end{array}$ & $\begin{array}{l}\text { Luteal Phase } \\
\left(22-23^{\text {th }} \text { day }\right)\end{array}$ & \multirow[b]{2}{*}{$\mathbf{P}$} \\
\hline & Mean \pm SD & Mean \pm SD & Mean \pm SD & \\
\hline Running time (min) & $17.01 \pm 2.45$ & $16.51 \pm 2.12$ & $16.85 \pm 1.68$ & 0.857 \\
\hline Peak HR (bpm/min) & $187.75 \pm 4.78$ & $187.50 \pm 4.04$ & $190.50 \pm 4.54$ & 0.148 \\
\hline
\end{tabular}

Peak HR (bpm/min): Peak heart rate; bpm: Per minute beat; min: minute; Sd:Standard deviation

\section{Discussion}

The purpose of this study is to examine the changes in aerobic-anaerobic capacity, maximal strength, strength endurance and heart rate during menstrual phases of women doing kickboxing. As a result of the study, it was found that hormonal changes in menstrual cycles did not affect performance. When studies conducted were examined, it was stated by various authors that menstrual period did not increase or decrease performance (Jaffre et al., 2006; Uçdağ, 2011; Aras et al., 2016). In their study, Wiecek at al. (2016) reported that hormonal changes in the middle of follicular phase and luteal phase during menstrual cycle did not affect women in terms of anaerobic performance, while in another study it was reported that menstrual cycle did not influence peak power, average power and lactate intensity (Tsampoukos et al., 2010). Results obtained from contemporary studies are similar to results found in literature. Another significant result of the study is the fact that rested heart rate responses of women in different phases of their menstrual cycles were not different. Similar results were found in similar studies (Teixeira et al., 2012; Aras et al., 2016).

In the present study, it was found that menstrual cycle did not affect running performance, that is, aerobic performance and maximal heart rate. In studies in which participants continued with treadmill until they were exhausted, it was reported that follicular phase and luteal phase did not increase exhaustion time (McCracken et al., 1994; Bemben et al., 1995); similarly, other studies conducted with cycling ergometer reported that menstrual phases did not increase exhaustion time and physiological parameters (Wei et al., 1999; Smekal et al., 2007). In another study conducted, it was shown that luteal and follicular phases did not influence maximal oxygen consumption and peak heart rate in 2000 meters rowing test (Forsyth \& Reilly, 2008). In their study, Uçdağ (2011) reported that aerobic endurance $\left(\mathrm{Maks} \mathrm{VO}_{2}\right)$ was not influenced by luteal and follicular phases. Unlike these studies, some studies reported that in elite athletes running distance decreased in aerobic running test (Yo-Yo IET) during luteal phase while jumping and running performance were not influenced (Julian et al., 2017). A mild decrease was also reported in VO2maks during luteal phase (Bemben et al., 1995), and oxygen consumption was reported to increase as 5.2\% with a metabolic speed increase of $5.6 \%$ and a decrease of 5.3\% in net efficiency (Hessemer \& Bruck, 1985).

In their study they conducted on sedentary women, Bandyopadhyay \& Dalui (2012) grouped menstrual cycle phases similar to our study and reported that maximal oxygen consumption, running time, and Peak $\mathrm{HR}$ on the third day after menstrual bleeding started were lower than follicular and luteal phase while no difference was found between rate and systolic- diastolic blood pressure. Although the menstrual phases of our study conducted with trained kickboxing women were similar to the phases of Bandyopadhyay \& Dalui (2012)'s study, different results were found. It is thought that the differences in these two studies may be due to different physical capacities and training levels of women. In these studies conducted, no consensus was reached due to differences in the effects of menstrual cycle on aerobic performance. Beidleman et al. (1999) suggested that the reason for these differences was due to heat regulation, substrate presence and differences in metabolism.

In the present study, it was concluded that muscle strength and muscle endurance were also not influenced by menstrual cycle. In their study Fridén, Hirschberg \& Saartok (2003) reported that menstrual cycle phases did not influence muscle strength and muscle endurance. In other studies conducted, it was reported that leg muscle strength, gripping strength and muscle functions were not influenced by menstrual cycle (Jonge et al., 2001; Elliott et al., 2003; Bambaeichi et al., 2004; Dias et al., 2005). Unlike these studies, Simao et al. (2008) found significant decreases in strength of women in follicular phase. In their study, Gordon et al. (2013) found that sex hormones related with menstrual periods caused fluctuations in peak power values in isokinetic strength measurement and thus strength trainings in women should be planned according to this cycle.

While some studies in literature report that female physiology is not influenced by hormonal changes in menstrual cycle (Janse, 2003; Redman \& Weatherby, 2004; Nattiv et al., 2007), it is still being discussed whether endocrine oscillations influence performance (Loureiro et al., 2011). While some studies show that the changes in oestrogen-progesterone serum concentrations are not enough to influence physical performance (Leitao et al., 2000; Friden et al., 2003), other studies report that the changes in some phases of the menstrual cycle cause better performance (Simao et al., 2008; Petrofsky et al., 2007). 


\section{Conclusion}

Kickboxing is a complex sport since it requires anaerobic capacity because of the need of sudden explosiveness and very high intensities of energy metabolism; aerobic capacity because of the need to recover faster during intervals of rounds and competitions and to get tired later during competition; and strength endurance to maintain aerobic capacity and strength. Women athletes are generally exposed to menstrual cycle once a month during their sport life. Thus, it is a common view among women athletes that hormonal levels change in the organism during menstrual cycle and they can be exposed to loss of blood and intense pain meanwhile. However, in this study, neither increase nor decrease was found in the aerobic-anaerobic or strength parameters of the participants of this study. Although there is no consensus in literature about the influence of menstrual cycle on performance, a great number of contemporary studies report that hormonal changes in menstrual phases do not influence performance.

\section{Acknowledgements}

The author declare no conflicts of interest at any stage of the study. The investigator would like to thank all subjects for their participation in this study.The author declare that no sources of funding were used in the preparation of this article.

\section{References}

Aras, D., Arslan, E., Atlı, A., \& Şahin, F. N. (2016). Menstrual döngünün fazlarına göre sedanter kadınlarda anaerobik güç değerlerinin incelenmesi. Ankara Üniversitesi Spor Bilimleri Fakültesi Spormetre Dergisi, 14(2), 191-198.

Arı̈z, A., \& Ege, E. (2013). Premenstrüel sendrom sorunu olan üniversite öğrencilerinde, semptomların kontrolü ve yaşam kalitesinin artırılmasında eğitimin etkinliği. Genel Tip Dergisi, 23(3), 63-69.

Bai, X., Li, J., Zhou, L., \& Li, X. (2009). Influence of the menstrual cycle on nonlinear properties of heart rate variability in young women. American Journal of Physiology-Heart and Circulatory Physiology, 297(2), 765-774. https://doi.org/10.1152/ajpheart.01283.2008

Bambaeichi, E., Reilly, T., Cable, N. T., \& Giacomoni, M. (2004). The isolated and combined effects of menstrual cycle phase and time-of-day on muscle strength of eumenorrheic females. Chronobiology International, 21(4-5), 645-660. https://doi.org/10.1081/CBI-120039206

Bandyopadhyay, A., \& Dalui, R. (2012). Endurance capacity and cardiorespiratory responses in sedentary females during different phases of menstrual cycle. Kathmandu Univ. Med. J., 10(4), 25-29.

Beidleman, B. A., Rock, P. B., Muza, S. R., Fulco, C. S., Forte Jr, V. A., \& Cymerman, A. (1999). Exercise and physical performance at altitude are not affected by menstrual cycle phase. Journal of Applied Physiology, 86(5), 1519-1526. https://doi.org/10.1152/jappl.1999.86.5.1519

Bell, D. R., Myrick, M. P., Blackburn, J. T., Shultz, S. J., Guskiewicz, K. M., \& Padua, D. A. (2009). The effect of menstrual-cycle phase on hamstring extensibility and muscle stiffness. Journal of Sport Rehabilitation, 18(4), 553-563. https://doi.org/10.1123/jsr.18.4.553

Bemben, D. A., Salm, P. C., \& Salm, A. J. (1995). Ventilatory and blood lactate responses to maximal treadmill exercise during the menstrual cycle. The Journal of Sports Medicine and Physical Fitness, 35(4), 257-262.

Beynnon, B. D., Johnson, R. J., Braun, S., Sargent, M., Bernstein, I. M., Skelly, J. M., \& Vacek, P. M. (2006). The relationship between menstrual cycle phase and anterior cruciate ligament injury: a case-control study of recreational alpine skiers. The American Journal of Sports Medicine,34(5), 757-764. https://doi.org/10.1177/0363546505282624

Dias, I. B. F., Simão, R., \& da Silva Novaes, J. (2005). Efeito das diferentes fases do ciclo menstrual em um teste de 10RM. Fitness \& Performance Journal, (5), 288-292.

Elliott, K. J., Cable, N. T., Reilly, T., \& Diver, M. J. (2003). Effect of menstrual cycle phase on the concentration of bioavailable 17- $\beta$ oestradiol and testosterone and muscle strength. Clinical Science, 105(6), 663-669. https://doi.org/10.1042/CS20020360

Forsyth, J. J., \& Reilly, T. (2008). The effect of menstrual cycle on 2000-m rowing ergometry performance. European Journal of Sport Science, 8(6), 351-357. https://doi.org/10.1080/17461390802308644

Fridén, C., Hirschberg, A. L., \& Saartok, T. (2003). Muscle strength and endurance do not significantly vary across 3 phases of the menstrual cycle in moderately active premenopausal women. Clinical Journal of Sport Medicine, 13(4), 238-241. https://doi.org/10.1097/00042752-200307000-00007

Fu, Q., VanGundy, T. B., Shibata, S., Auchus, R. J., Williams, G. H., \& Levine, B. D. (2010). Menstrual cycle affects renal-adrenal and hemodynamic responses during prolonged standing in the postural orthostatic tachycardia 
syndrome. Hypertension, 56(1), 82-90. https://doi.org/10.1161/HYPERTENSIONAHA.110.151787

Giacomoni, M., Bernard, T., Gavarry, O., Altare, S., \& Falgairette, G. (2000). Influence of the menstrual cycle phase and menstrual symptoms on maximal anaerobic performance. Medicine and science in sports and exercise, 32(2), 486-492. https://doi.org/10.1097/00005768-200002000-00034

Gordon, D., Hughes, F., Young, K., Scruton, A., Keiller, D., Caddy, O., \& Barnes, R. (2013). The effects of menstrual cycle phase on the development of peak torque under isokinetic conditions. Isokinetics and Exercise Science, 21(4), 285-291.

Hessemer, V., \& Bruck, K. (1985). Influence of menstrual cycle on shivering, skin blood flow, and sweating responses measured at night. Journal of Applied Physiology, 59(6), 1902-1910. https://doi.org/10.1152/jappl.1985.59.6.1902

Heyward, V. H., \& Gibson, A. (2014). Advanced fitness assessment and exercise prescription 7th edition. Human kinetics.

Jaffre, C., Zouhal, H., Rannou, F., Delamarche, P., \& Gratas-Delamarche, A. (2006). Menstrual cycle effect or oral contraceptive therapy on Wingate-test performance. Science and Sports, 21(1), 20-22.

Janse de Jonge X.A.K.(2003). Effects of the menstrual cycle on exercise performance. Sports Med., 33(11), 833-51. https://doi.org/10.2165/00007256-200333110-00004

Jonge, X. A. K., Boot, C. R. L., Thom, J. M., Ruell, P. A., \& Thompson, M. W. (2001). The influence of menstrual cycle phase on skeletal muscle contractile characteristics in humans. The Journal of Physiology, 530(1), 161-166. https://doi.org/10.1111/j.1469-7793.2001.0161m.x

Julian, R., Hecksteden, A., Fullagar, H. H., \& Meyer, T. (2017). The effects of menstrual cycle phase on physical performance in female soccer players. PloS one, 12(3). https://doi.org/10.1371/journal.pone.0173951

Kabalak, T. C., Tüzün, Y. M. Endokrinoloji El Kitabı, İzmir Güven Kitabevi, İzmir; 2004.

Karabag, T., Hanci, V., Aydin, M., Dogan, S. M., Turan, I. O., Yildirim, N., \& Gudul, N. E. (2011). Influence of menstrual cycle on P wave dispersion. International Heart Journal, 52(1), 23-26. https://doi.org/10.1536/ihj.52.23

Leitão, M. B., Lazzoli, J. K., Oliveira, M. A. B. D., Nóbrega, A. C. L. D., Silveira, G. G. D., Carvalho, T. D., \& Drummond, F. A. (2000). Posicionamento oficial da Sociedade Brasileira de Medicina do Esporte: atividade física e saúde na mulher. Revista Brasileira de Medicina do Esporte, 6(6), 215-220. https://doi.org/10.1590/S1517-86922000000600001

Loureiro, S., Dias, I., Sales, D., Alessi, I., Simão, R., \& Fermino, R. C. (2011). Effect of different phases of the menstrual cycle on the performance of muscular strength in 10RM. Revista Brasileira de Medicina do Esporte, 17(1), 22-25. https://doi.org/10.1590/S1517-86922011000100004

McCracken, M., Ainsworth, B., \& Hackney, A. C. (1994). Effects of the menstrual cycle phase on the blood lactate responses to exercise. European Journal of Applied Physiology and Occupational Physiology, 69(2), 174-175. https://doi.org/10.1007/BF00609412

Miller, T., \& Conditioning Association. (2012). NSCA's Guide to Tests and Assessments. Human Kinetics.

Nattiv, A., Loucks, A. B., Manore, M. M., Sanborn, C. F., Sundgot-Borgen, J., \&Warren, M. P. (2007). American college of sports medicine - Position stand. The female athlete triad. Med. Sci. Sports Exerc., 39, 1867-1882.

Oosthuyse, T., \& Bosch, A. N. (2010). The effect of the menstrual cycle on exercise metabolism. Sports Medicine, 40(3), 207-227. https://doi.org/10.2165/11317090-000000000-00000

Petrofsky, J., Al Malty, A., \& Suh, H. J. (2007). Isometric endurance, body and skin temperature and limb and skin blood flow during the menstrual cycle. Med. Sci. Monit., 13(3), 111-117.

Redman, L. M., \& Weatherby, R. P. (2004). Measuring performance during the menstrual cycle: a model using oral contraceptives. Medicine and Science in Sports and Exercise, 36(1), 130-136. https://doi.org/10.1249/01.MSS.0000106181.52102.99

Reneta, J. F., \&Constance, L. M. (2000). Menstrual cycle, contraception and performance. Clinics in Sports Medicine, 19(2), 251-271. https://doi.org/10.1016/S0278-5919(05)70202-7

Rosenfeld, J. A. (Ed). (2009). Handbook of women's health. Cambridge University Press. https://doi.org/10.1017/CBO9780511642111

Saladin, K. S. Anatomy And Physiology: the unity of form and function. The McGraw-Hill.Eighth Edition; 2016.

Simão, R., Maior, A. S., Nunes, A. P. L., Monteiro, L., \& Chaves, C. P. G. (2008). Variações na força muscular de 
membros superior e inferior nas diferentes fases do ciclo menstrual. Revista Brasileira de Ciência $e$ Movimento, 15(3), 47-52.

Smekal, G., Von Duvillard, S. P., Frigo, P., Tegelhofer, T., Pokan, R., Hofmann, P., \& Bachl, N. (2007). Menstrual cycle: no effect on exercise cardiorespiratory variables or blood lactate concentration. Medicine \& Science in Sports \& Exercise, 39(7), 1098-1106. https://doi.org/10.1249/mss.0b013e31805371e7

Teixeira, A. L. S., Júnior, W. F., Moraes, E. M., Alves, H. B., Damasceno, V. D. O., \& Dias, M. R. C. (2012). Effects of menstrual cycle phase on resting heart rate in healthy women. Journal of Exercise Physiology Online, 15(4).

Tsampoukos, A., Peckham, E. A., James, R., \& Nevill, M. E. (2010). Effect of menstrual cycle phase on sprinting performance. European Journal of Applied Physiology, 109(4), 659-667. https://doi.org/10.1007/s00421-010-1384-z

Turan, T., \& Ceylan, S. S. (2007). 11-14 yaş grubu ilköğretim öğrencilerinin menstruasyona yönelik bilgileri ve uygulamaları. Firat Sağllk Hizmetleri Dergisi, 2(6), 41-53.

Üçdağ, G. (2011). Elit kadın sporcularda menstruel evrelerin esenlik düzeyi ve performansa olan etkisi. Doktora tezi, Marmara Üniversitesi Sağllk Bilimleri Enstitüsü, İstanbul (Danışman: Prof. Dr. A Pehlivan).

Wei, M., Kampert, J. B., Barlow, C. E., Nichaman, M. Z., Gibbons, L. W., Paffenbarger Jr, R. S., \& Blair, S. N. (1999). Relationship between low cardiorespiratory fitness and mortality in normal-weight, overweight, and obese men. Jama, 282(16), 1547-1553. https://doi.org/10.1001/jama.282.16.1547

Wiecek, M., Szymura, J., Maciejczyk, M., Cempla, J., \& Szygula, Z. (2016). Effect of sex and menstrual cycle in women on starting speed, anaerobic endurance and muscle power. Acta Physiologica Hungarica, 103(1), 127-132. https://doi.org/10.1556/036.103.2016.1.13

\section{Copyrights}

Copyright for this article is retained by the author(s), with first publication rights granted to the journal.

This is an open-access article distributed under the terms and conditions of the Creative Commons Attribution license which permits unrestricted use, distribution, and reproduction in any medium, provided the original work is properly cited. 